\title{
Transducing a Sermon, Inducing Conversion
}

\section{Citation}

Harkness, Nicholas. 2017. "Transducing a Sermon, Inducing Conversion." Representations 137 (1) (February): 112-142. doi:10.1525/rep.2017.137.1.112.

\section{Published Version}

10.1525/rep.2017.137.1.112

\section{Permanent link}

http://nrs.harvard.edu/urn-3:HUL.InstRepos:33459438

\section{Terms of Use}

This article was downloaded from Harvard University's DASH repository, and is made available under the terms and conditions applicable to Other Posted Material, as set forth at http:// nrs.harvard.edu/urn-3:HUL.InstRepos:dash.current.terms-of-use\#LAA

\section{Share Your Story}

The Harvard community has made this article openly available.

Please share how this access benefits you. Submit a story.

Accessibility 


\section{Transducing a Sermon, Inducing Conversion: Billy Graham, Billy Kim, and the 1973 Crusade in Seoul}

\section{Evangelical Pressures of Speech}

IN THE SPRING OF 1973, the American evangelist Billy Graham traveled to Seoul, South Korea, for one of his famous crusades. The evangelical campaign took place on Yoido, an island along the Han River. Although this island would emerge over the next decades as a dense urban center of government, finance, and broadcasting, in 1973 it still was largely an empty plot of sandy earth. ${ }^{1}$ General Park Chung-hee, the autocratic ruler of South Korea from 1961 until his assassination in 1979, gave permission for organizers to hold their crusade on an asphalt expanse on Yoido that was used for official state events and military demonstrations. Prior to that, the area had been used as an airstrip by the US military and, earlier, by the Japanese colonial government. On May 30, the first day of the event, more than 300,000 people attended. Each day, the crusade grew in attendance. On June 3, the fifth and final day, Graham preached to a crowd estimated to exceed one million (fig. 1). ${ }^{2}$ It was the largest crowd ever amassed for a Billy Graham event.

Next to Billy Graham at the pulpit, and backed by a choir of 6,000 singers, was Billy Jang Hwan Kim, the South Korean minister of Suwŏn Baptist Church, who reproduced Graham's sermon verbally and periverbally-utterance by utterance, tone by tone, gesture by gesture-for the

A B S T RACT This paper is an analysis of the final sermon of Billy Graham's 1973 Crusade in Seoul, South Korea, when he preached to a crowd estimated to exceed one million people. Next to Graham at the pulpit was Billy Jang Hwan Kim, a preacher who, in his capacity as interpreter, translated Graham's sermon verbally and peri-verbally-utterance by utterance, tone by tone, gesture by gesture-for the Koreanspeaking audience. I examine the dynamic pragmatics (for example, chronotopic formulations, deictic calibrations, voicing and register effects, and indexical dimensions of entextualization) by which a sermonic copy across linguistic codes became an evangelical conduit between Cold War polities. In so doing, I demonstrate how the scope of intertextual analysis can be expanded productively from the narrow translation of denotation across codes to the broader indexical processes of semiotic "transduction" across domains of cultural semiosis. REPRESENTA TIONS 137. Winter 2017 (C) The Regents of the University of California. ISSN 0734-6018, electronic ISSN 1533-855X, pages 112-42. All rights reserved. Direct requests for permission to photocopy or reproduce article content to the University of California Press at http:// www.ucpress.edu/journals.php?p=reprints. DOI: https://doi.org/10.1525/rep.2017.137.6.112. 


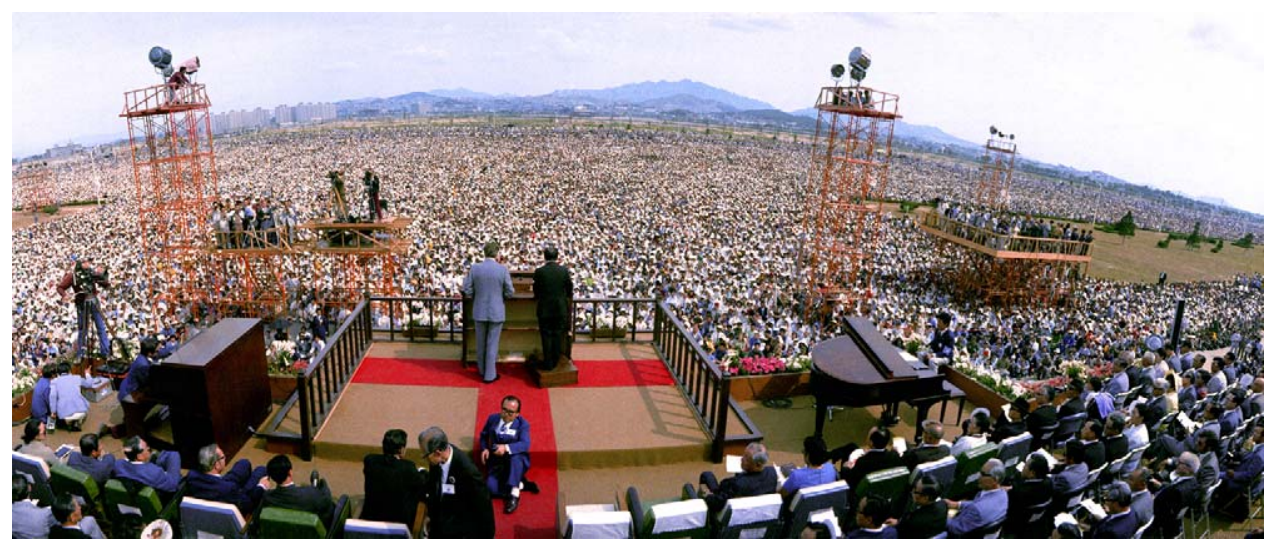

FIGURE 1 .

Korean-speaking audience. ${ }^{3}$ Kim explained in his autobiography that he watched film footage of Billy Graham's preaching so that he could "practice the accents, gestures, and intonations of Billy Graham" in order to "become a Korean-speaking Billy Graham" for those five days. ${ }^{4}$ In documentary footage of the event, Kim explained that while his own style at the pulpit was different from Graham's, for those five days he did not want to "divert," "change," or make Graham's message "any different" from what or how Graham preached. ${ }^{5}$ Kim described the interactional effect of interpreting for Billy Graham as two voices becoming one voice. ${ }^{6}$ He explained this accomplishment in supernatural terms: "Well, once I got in with him, I didn't even know what I was doing. And I think I was completely influenced by the force that, uh, you know, we call the Holy Spirit."7

Christian leaders in South Korea praised Kim's performance. Pastor Kim Kyong Nae, secretary general of the crusade, described Kim's interpretation as capturing Graham's "spiritual flow” (yŏngchǒk in hŭrŭm) and characterized the interaction of the two preachers as one of "harmony." 8 Pastor Pang Chi Il, a member of the organizing committee for the crusade, claimed that Kim had not translated ( pŏnyŏk) Graham's sermon at all. Rather, according to Pastor Pang, Kim seemed to have given his own sermon, which, Pang claimed, is why it had made such a deep impression (kammyŏng) on the audience. ${ }^{9}$ There was similar praise from US Christians who witnessed Kim's performance. According to Billy Graham's official biographer, "Billy Kim actually enhanced Billy Graham. In gesture, tone, force of expression, the two men became as one in a way almost uncanny. A missionary fluent in Korean who knew Graham personally thought that Kim's voice even sounded like Graham's. Some TV viewers, tuning in unawares, supposed Kim the preacher and Billy Graham the interpreter for the American 
forces." ${ }^{10}$ Henry Holley, Billy Graham's Crusade Director for Asia, put it simply: "The two of them functioned as one." ${ }^{11}$ At a press conference during his trip to Seoul, Graham himself thanked the thousands in Korea who had been "working and praying and preparing" for the success of the crusade and then added: "And I would be absolutely nothing were it not for my good voice, Billy Kim." 12

I have two aims for this paper. First, I want to reveal in detail the semiotic processes of synchronization and calibration by which Billy Kim's sequential interpretation of Billy Graham's sermon into Korean for a Korean-speaking audience had the semiotic effect of fusing two voices into one. These processes complicate the question of "who" was speaking at any given moment, and they suggest that we must investigate higher-order cultural frameworks that make these processes semiotically legitimate for participants. Second, I attempt to demonstrate how this semiotic fusion of voices drew upon and intensified the very ideological principles of evangelism that brought these two men to the pulpit and justified their speech in Seoul in 1973. As I explain in detail in what follows, this analysis hinges on our methodological expansion from the narrow translation of denotational text to a broader semiotic "transduction" of indexicality through which denotational text emerges interactionally. ${ }^{13}$ Although I cannot adequately represent the virtuosity of the performance, my analysis focuses on the dynamic pragmatics of this historic event documented in a film recording that captures the increasingly dense layering of temporal and spatial deixis across codes, the compounding of vocalizations and figurative voicings across speakers, and the way these semiotic dimensions of preaching linked theological principles of radical universality to personal experiences of radical individuation. ${ }^{14}$

\section{Translation, Transduction, and the Transitive "Principal" of Evangelism}

The first step in my analysis is to shift focus from the denotational (semantico-referential) translation of "words for things" across codes to the pragmatic (indexical) "transduction" of the broader set of semiotic phenomena through which denotational texts-in-context emerge and congeal. Semiotic transduction, broadly conceived, takes into account the problem of indexicality and the coconstitutive processes of entextualization and contextualization, thus highlighting the varying degrees of contextualization implicit in all denotational texts, verbally uttered or graphically inscribed, complete or partial. ${ }^{15}$ This expansion from the relatively narrow function of denotation to the broader polyfunctionality of pragmatics makes available for analysis the various self-authorizing ideological dimensions of language 
that are invoked in speech, contribute to performative efficacy in interaction, and must be managed, that is, transduced, in events of translation. ${ }^{16}$

In the genre of the evangelical sermon, the complex, often unclear relationship between the preacher and the authorship of the utterances preached can be mobilized for strategic ends: a marked liveliness of preaching can be construed as inspired and therefore authorized; strangersociability among members of an audience who are unknown to one another can be accommodated and shaped into Christian fellowship; conversions can be claimed when the speech of the audience manifests in utterances that resemble those of the preacher. ${ }^{17}$ At a press conference in Seoul during his 1973 visit, Graham drew explicitly on these aspects of the evangelical tradition when he announced that he had "come as a representative of the kingdom of God" and explained that his evangelical approach was based on his belief that "the Bible is the inspired word of God." ${ }^{18}$ Nearly two decades earlier, Roland Barthes described Graham's crusade in Paris in 1955 in similar, if sarcastic terms: "Here, from the first minute, Billy Graham is presented as a veritable prophet, into whom we beg the Spirit of God to consent to descend, on this very evening in particular: it is an Inspired Being who will speak, the public is invited to the spectacle of a possession: we are asked in advance to take Billy Graham's speeches quite literally for divine words." ${ }^{19}$ On the topic of Graham's first "back-to-the-Bible campaign" in a predominantly Catholic country, when he preached to average crowds of 8,000 people, the evangelist himself reported that "it was the most amazing response I have ever seen. A new spirit seemed to form on the congregation after the initial difficulties of interpretation and acoustics. I feel that God did it." ${ }^{20}$ According to the language ideology of this early instance of a Billy Graham revival performed in two linguistic codes, the "Word" was treated as if it had been delegated to Graham by the deity. Graham in turn delegated the "Word" to the Baptist Reverend Jacques Blocher, who stood beside Graham in Paris in 1955 and "repeated Graham's sermon in French into microphones and duplicated virtually every one of Graham's clenched fist and jabbing finger gestures." ${ }^{21}$ This model would reach its apex of both virtuosity of performance and scale of attendance in Seoul in 1973.

In order to preach across different linguistic-cultural contexts, evangelists like Graham rely on an ideology of the literal denotation of biblical assertion as justification for attempting to preserve a fundamental likeness of speech across all possible conditions of semiotic difference. ${ }^{22}$ This fundamental likeness, grounded in a specifically religious ideology of the "Word" as both eternal and flawless on the one hand, and living and adaptable to different sociohistorical conditions on the other, supports a metaphor of movement that is appropriated in the description of evangelism itself: Christians should "spread" the gospel, "carry" the "Word," "bring" the truth, 
and so on. This mode of conceptualizing semiosis as movement is made possible by a kind of cultural apperception, where a perceived serial ordering of these events over time, interdiscursively linking one with respect to another, and a perceived intertextual likeness across events of semiotic production, combine to produce an effect similar to the lights that seem to "move" on a marquee. ${ }^{23}$ The likeness of the "Word" across time and space, recorded in Bibles, carried by evangelists, and placed directly into the mouths of preachers and the prayerful, becomes the very material in terms of which the force of evangelical oratory can be conceptualized. This ideology of language as words-in-motion across both earthly and spiritual channels can be mobilized to resolve the logical tension between the "Word" as both eternal and living, flawless and adaptive. ${ }^{24}$

An ideology of the inerrancy of the "Word" also plays a role in the elicitation of confession and the induction of conversion. When one prays, preaches, or simply asserts biblical truths, each individual is supposed to align his or her specific inner belief with collective outer forms of expression within a Christian model of "sincere," "earnest" speech. ${ }^{25}$ The ideology of sincerity here depends upon a notion of the individuated, distinct, radically personal relationship with the deity and such a relationship's mediation by various forms of spiritual semiosis. And yet the very media through which one prays, preaches, or asserts biblical truth are largely unoriginal and unindividuated. While Christians are supposed to be biographically specific and radically individuated before God (for example, the very hairs of their heads being numbered, and so on), Christian speech should be thoroughly generic and radically universal insofar as it approximates eternal, flawless biblical assertions. This basic contradiction is brought to the fore in the genre of the sermon. In her study of Jerry Falwell, an evangelical minister who rose to fame in the United States in the late 1970s and 1980s, Susan Friend Harding notes:

Preachers are not bound by intellectual property rights, and among them piracy is not a vice, it is a virtue. They may borrow aggressively from one another, appropriating exegeses, illustrations, stories, quotations, logics, style, tone, gestures, and even entire sermons without citation. Their skills of imitation and impersonation, and whom they choose to imitate and impersonate, in part determines their audience and their reach. ${ }^{26}$

In precisely this way, the coordinated performance of Billy Graham and Billy Kim at the 1973 crusade serves as an extreme amplification of Webb Keane's observation from the eastern Indonesian island of Sumba, where Christian "adults must confirm their true faith in a public performance, one of an endless series of socially grounded affirmations. And such confirmations are themselves a discursive pedagogy, as they work to transform 
individuals, in Susan Harding's astute observation, from listeners into sincere speakers of the language of faith." ${ }^{27}$ In the live interpretation of sermons across codes, interpreters themselves are generally already known and self-identified as Christians, so the act of interpretation itself becomes at least a partial act of religious self-fashioning.

The 1973 crusade was preceded by revivals around South Korea that were designed to prepare South Koreans for Billy Graham's visit. These events were part of a larger trend following the Korean War, when numerous revivals and evangelistic campaigns in South Korea contributed to the dramatic growth of Protestant Christianity in the country from a mere 3 or 4 percent around 1960 to between 20 and 25 percent by the 1990s. ${ }^{28}$ These orchestrated events of Korean Christian self-evangelism helped to produce the ubiquitous evangelical ethos that is said to pervade contemporary South Korean Protestant Christianity. According to this ethos, the religious obligation is not merely to be a sincere speaker of the language of faith, but also to address that language persuasively to others: to evangelize, proselytize, missionize. In many ways, to be a Korean Christian has been to be an evangelist. ${ }^{29}$

Christian evangelizing, proselytizing, and missionizing of the sort just described operates by speaking "in the name of Jesus" (Yesunim üi irüm üro), that is, by appropriating the authority and interest of Jesus, if not necessarily Jesus's precise utterances. According to Erving Goffman's classic "production format" model of role partials in verbal interaction, the "author" composes an utterance, the "animator" materializes it, and the "principal" is responsible for or has an interest (in the legalistic sense) in it. ${ }^{30}$ The ideal Christian speech that I discuss in this paper thus operates-to make a Goffmanian pun-according to a transitive "principal" of evangelism. And the interpreter of evangelical speech-in 1973, Billy Kim interpreting for Billy Grahambecomes a kind of conduit, translating denotational text and transducing the cultural semiotics of sincerity, conviction, emotionality, and so forth. This process of semiotic transduction brings the eternal, flawless, living "Word" in its fullest, most potent sense, to a new audience in a new code.

In the analysis that follows, I focus on three semiotic dimensions that are particularly salient to the processes of sermonic transduction and the transitive "principal" of evangelism. These dimensions help us to understand how the sermon develops intersecting narratives that chart relations among different, often competing authors, animators, principals, and characterological figures. The first dimension is the way a particular combination of these narratives in the real-time unfolding of the sermon formulates a deictic scaffolding of time, space, and person-a narrative "chronotope"-of sacrifice and evangelism in terms of which to situate the 1973 crusade and its participants. ${ }^{31}$ The second is the way the two pastors populate this emergent chronotope by manipulating their individual acts of vocalization in relation to an 
emergent moral "voicing" structure of characterological figures that serve as personified points of orientation for the judgment of speech, thought, and other actions. ${ }^{32}$ Finally, the third is the introduction of biblical scripture qua "authoritative word," that is, a denotational model of ideal speech and, more broadly, a pragmatic model of social interaction that mediates between the allocentric orientation to universal truth and the egocentric orientation to individual conversion. ${ }^{33}$ These three processes combine and compound to produce a poetic series of indexical constraints on the interactional space into which the attendees are invited to participate, effectively narrowing and fixing the degrees of pragmatic freedom to yield a remarkable oratorical "force." 34 The intensifying interactions of the two pastors on stage reveal the complex semiotic processes that can transform a sermonic copy into an evangelical conduit for the movement of the "Word"-from speaker to speaker, from code to code, from country to country, from heaven to earth.

\section{Chronotopic Formulations of Sacrifice and Evangelism}

"Twenty-two years ago, I was here in Korea. It was at Christmastime. And it was very cold. I'd never been so cold in all my life. And I toured along what is now the DMZ." Thus began Billy Graham's final sermon of his Seoul Crusade, which took place two decades after the Korean Armistice Agreement that ended fighting in the Korean War in 1953. The first words of Graham's sermon began to formulate a moral chronotope of sacrifice that would link the then-present event of utterance to the slaughter and tragedy of the Korean War two decades prior, and then two millennia further back to the crucifixion. Graham recounted the actions in 1951 of an American soldier on "Heartbreak Ridge" who threw himself onto a grenade to protect his fellow soldiers. The soldier died but his friends were saved. This story operates as a familiar allegory of Christian self-sacrifice, which Graham later links to Jesus on the cross. As this moral time-space of sacrifice emerges from Graham's narrative, Graham introduces biblical scripture (John 15:13) that, along with sacrifice, links the time-space dimensions of the narrative to its moral import. Graham and Kim, referring each to his own copy of the Bible, in English and Korean respectively, recite the passage (which Graham claims be one of the greatest "in all of literature") that the clergyman read at the funeral of the sacrificed soldier (transcript 1, figs. 2-12).

\section{Transcript 1}

[25:25-25:53]

1. G: And when they held the memorial service for that soldier

2. K: Kŭ kunin ŭl wihaesŏ yebae rŭl tŭryŏssŭl ttae e 
3. G: The clergyman took the text that I want to take today.

4. K: Moksanim ŭi ponmun malssŭm $i$ onŭl che ka yŏrŏbundŭl ege tŭrinŭn paro kŭ malssŭm imnida.

5. G: It is found in John's gospel in the Bible.

6. K: Yohan pogŭm e innŭn malssŭm imnida.

[25:54-26:11 omitted]

[26:12-26:28]

7. G: Greater love hath no man than this that he lay down his life for his friends.

8. K: Saram i chagi ch'in'gu rŭl wihayŏ moksum ǔl pŏrimyŏn i e tŏ k'ŭn sarang $i$ ŏptago malssŭm haessŭmnida.

9. G: Now Jesus said this just before he was going to go to the cross.

10. K: Yesunim i i malssŭm ŭl hasin kŏt ŭn sipchaga kasigi chikchŏn e hasin malssŭm imnida.

[26:29-26:41 omitted]

[26:42-27:42]

11. G: And he said I have one commandment to leave with you.

12. K: Nae ka nŏhŭidŭl ege kkok han kaji myŏngnyŏng ŭl chul t'eda.

13. G: I want to say something I hope you'll never forget, he said.

14. K: Ije chejadŭl ege nae ka hanŭn mal ŭl yŏngwŏnhi irŏbŏriji marara.

15. G: Love one another!

16. K: Sŏro sarang hara!

17. G: Love one another!

18. K: Sŏro sarang hara!

19. G: Love one another!

20. K: Sŏro sarang hara!

21. G: He said I have only one commandment to leave.

22. K: Nae ka kyemyŏng ŭl chul kŏt i hana pakke ŏmnŭnira.

23. G: Love one another!

24. K: Sŏro sarang hara!

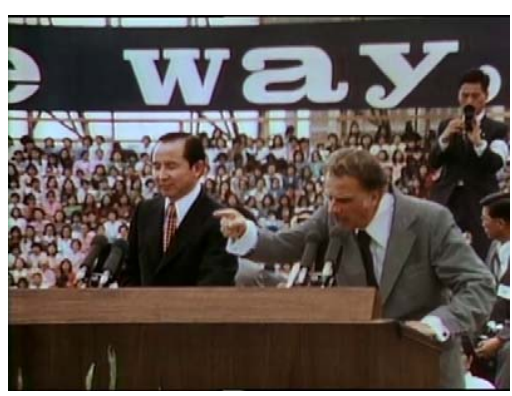

FIGURE 2 .

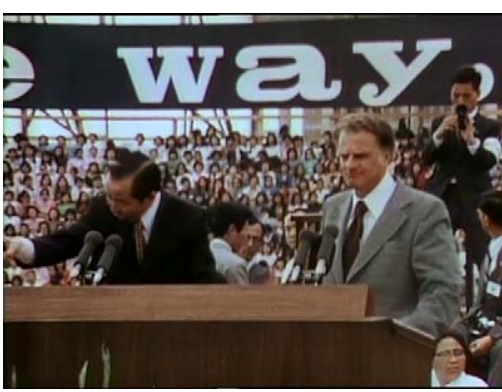

FIGURE 3 . 
25. G: He was getting ready to die.

26. K: Kŭ nŭn chukki chikchŏn imnida.

27. G: He was getting ready to leave.

28. K: Ije sesang ŭl ttŏnasil chikchŏn imnida.

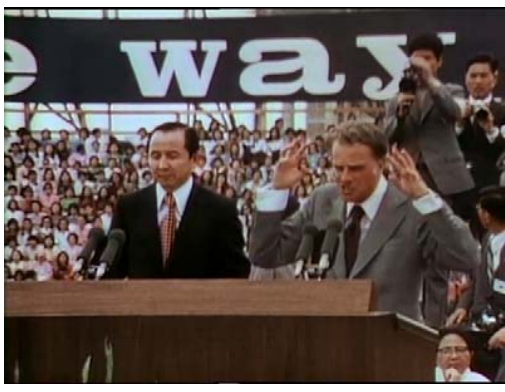

FIGURE 4.

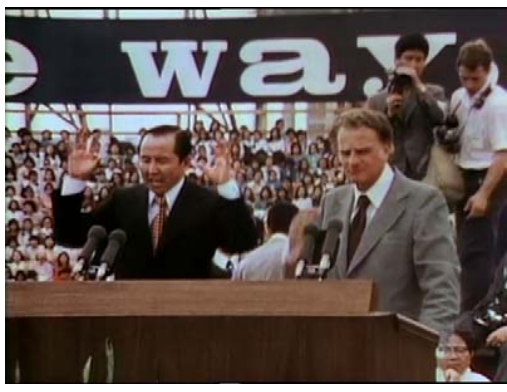

FIGURE 5 .

29. G: And the last words he said to the people was love each other.

30. K: Saramdŭl ege majimak chusinŭn malssŭm $i$ sŏro sarang hara.

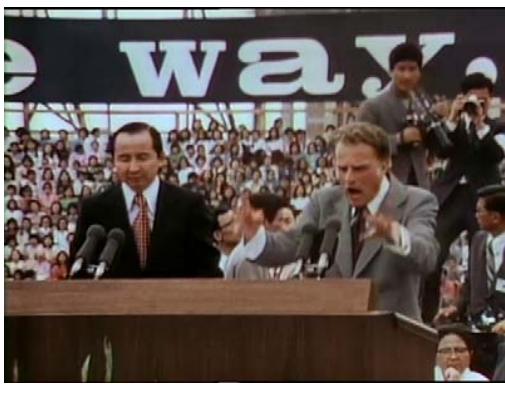

FIGURE 6 .

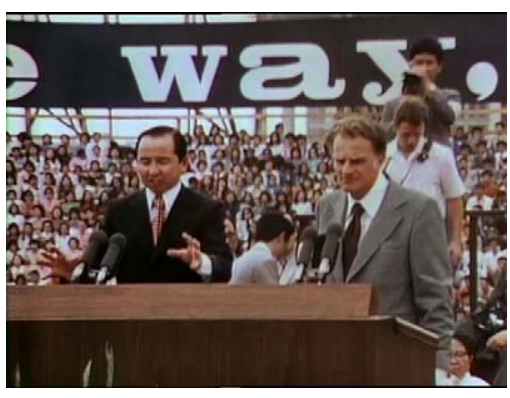

FIGURE 7 .

31. G: I say to you as Christians today.

32. K: Onŭl sŏngdo yŏrŏbundŭl ege che ka malssŭm tŭrigo sip’ŭn kŏt ŭn.

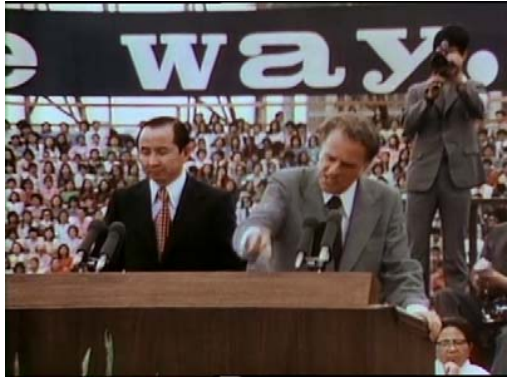

FIGURE 8 .

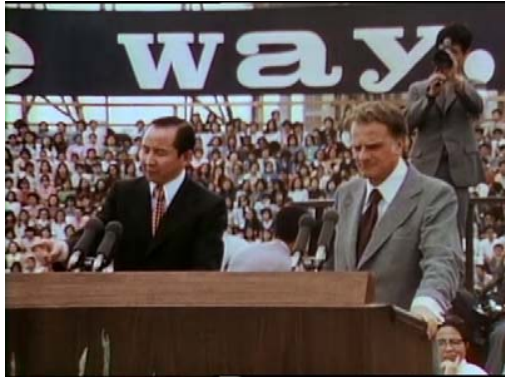

FIGURE 9. 
33. G: Love one another!

34. K: Sŏro sarang hasyŏya toemnida!

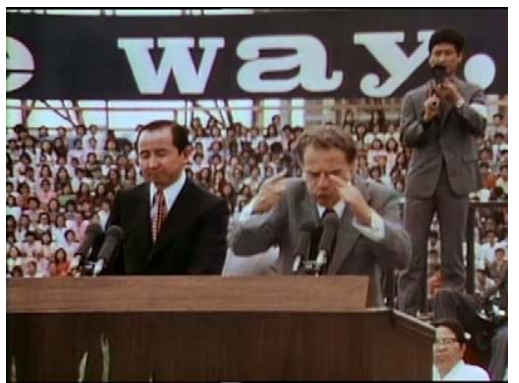

FIGURE 10 .

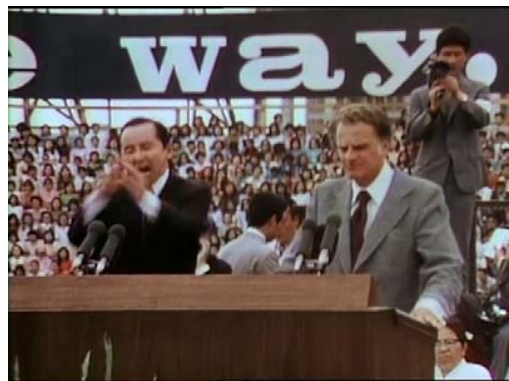

FIGURE 11.

35. G: And that is the message I want to leave as I go back to America: love one another in Korea!

36. K: Che ka ije Han'guk ŭl ttŏnasŏ Miguk e toraganŭnde majimak malssŭm i yŏrŏbundŭl ege sŏro sarang haranŭn malssŭm imnida!

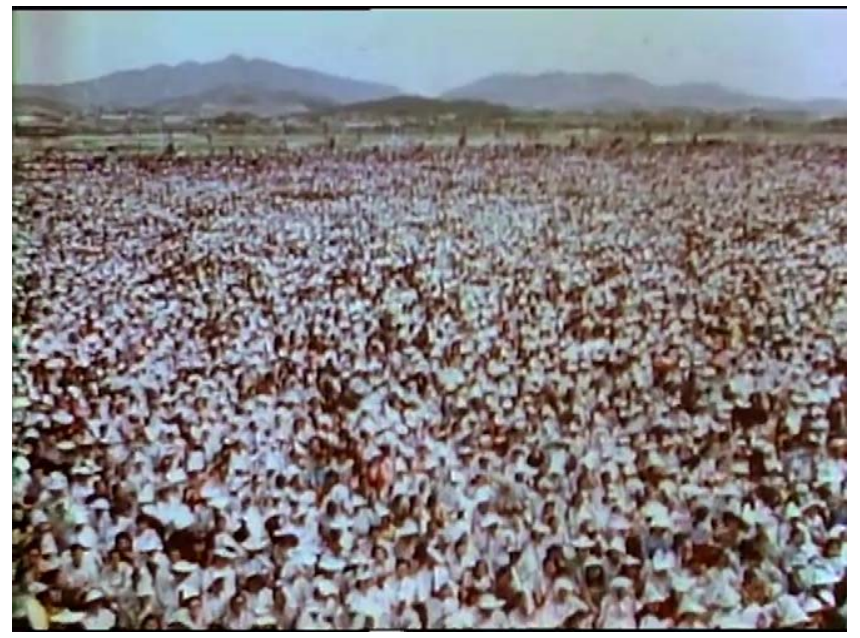

FIGURE 12.

In this opening passage, the funeral of the soldier, as a spatiotemporal medial point (there/then) in the moral chronotope of sacrifice provides a deictic bridge between the distal point (way-over-there/way-back-then) of Jesus's last supper and the proximal point (here/now) of the sermon, in which the voice of Jesus, the recitation of Bible verse, and Graham's and Kim's coordinated commands to the audience become linked (table 1). 
TABLE 1. Moral chronotope of sacrifice and evangelism

\begin{tabular}{|c|c|c|}
\hline Distal & Medial & Proximal \\
\hline $\begin{array}{l}\text { Way over there/ } \\
\text { way back then }\end{array}$ & There/then & Here/now \\
\hline Crucifixion & $\begin{array}{l}1951 \text { memorial for U.S. } \\
\text { soldier }\end{array}$ & 1973 crusade in Seoul \\
\hline $\begin{array}{l}\text { Jesus "getting ready to die" / } \\
\text { "getting ready to leave" }\end{array}$ & $\begin{array}{l}\text { Clergyman preparing } \\
\text { for burial }\end{array}$ & "as I go back to America" \\
\hline To the disciples and people & $\begin{array}{l}\text { To family and friends of } \\
\text { the departed }\end{array}$ & $\begin{array}{l}\text { "to you as Christians } \\
\text { today" }\end{array}$ \\
\hline "Love one another!" & "Love one another!" & "Love one another!" \\
\hline Sŏro sarang hara! & Sŏro sarang hara! & $\begin{array}{l}\text { Sŏro sarang hasyŏya } \\
\text { toemnida! (honorific) }\end{array}$ \\
\hline
\end{tabular}

As Graham and Kim proceed with their coordinated oration, the tight alignment of their communicative actions is fixed by deixis across linguistic codes and amplified by nearly identical gestures. ${ }^{35}$ This is made clearer by the shifting participant framework emergent from Kim's use of a relatively blunt command form in Korean to translate Graham's citation of the key phrase in the Bible passage being discussed: "Love one another!" (Soro sarang hara!). ${ }^{36}$ This command would have been spoken from a position of authority, that is, by Jesus or "in the name of Jesus." The command is first translated as having been spoken by Jesus to his disciples (cheja) and then to "the people" (saram). When the command is directed explicitly at the audience in Seoul, Kim strategically adds honorific deference indexicals to contextualize the utterance as being uttered "here" and "now" to "you" (yŏrŏbun sŏro sarang hasyŏya toemnida!). Shifts in spatiotemporal deixis lay the track for interactional sameness across time and space: Jesus said these words before he was going to "leave" and "die," the clergyman said them at the American soldier's funeral, and Billy Graham said them before "leaving" for America. Across these different utterances and their utterers, the strident vocalizations and dramatic visual gestures remain constant.

The moral chronotope of sacrifice and evangelism that emerges from Graham's opening narrative establishes a framework of orientation that metapragmatically situates and fixes the pragmatics of the crusade in historic time and space. Furthermore, by signaling both the arrival of the message and the departure of the messenger, the crusade takes on the character of rupture that is part and parcel of "world-breaking" and "world making" Christian conversion experiences. ${ }^{37}$ The message itself, distributed among different speakers, and furthermore distributed among different 
Goffmanian role partials-animator, author, principal—establishes relations of speech within a hierarchy of speech participants, which is then anchored to a key phrase that remains "the same" across all utterances in both languages, that is, denotationally "translatable" within the broader pragmatics of evangelical "transduction."

\section{The Pragmatics of Voice and Voicing}

In a country still raw from the Korean War, the sermonic event was situated within a moral Christian chronotope of transhistorical and transregional sacrifice. As the sermon proceeded, personifications of this moral timespace began to materialize in the sensuous qualities of the verbal medium itself-the "qualia" of the men's voices. ${ }^{38}$ Their strident vocalizations, for example, when calling out "love one another!" / "Soró sarang hara!" became the qualitative stamp of an event suffused with the values of conviction and urgency. However, different social voices-such as of Eve and Satan-enter the sermon as direct ethical and aesthetic contrasts to the strident voices of God, Jesus, and the two evangelists speaking "as themselves." Graham and Kim link these voices to actions-of Eve, Satan, and God in the Garden of Eden - that form a composite human first cause for which their deity-in-theflesh later would be sacrificed and in terms of which their evangelism in 1973 could be justified (transcript 2, figs. 13-22). According to the transitive "principal" of evangelism, their own ongoing phonic engagements with one another and with the audience produced a sonic framework of differentiation and value to which they could orient as they proceeded with their oratory.

\section{Transcript 2}

[35:51-36:18]

1. G: There's one tree in the garden you're not to touch.

2. K: Eden tongsan e innŭn yŏlmae [fruit] hana nŭn ttamŏkchi rŭl marara.

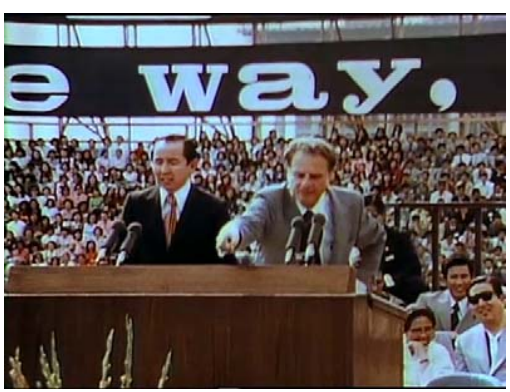

FIGURE 13.

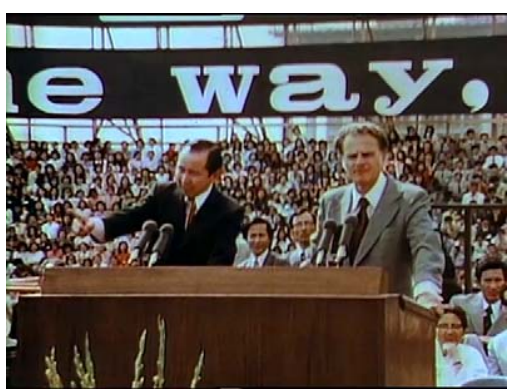

FIGURE 14 . 
3. G: If you touch it you'll die.

4. K: Ne ka kŭ kŏt ŭl [pick and eat] ttamŏgŭmyŏn chungnŭnda.

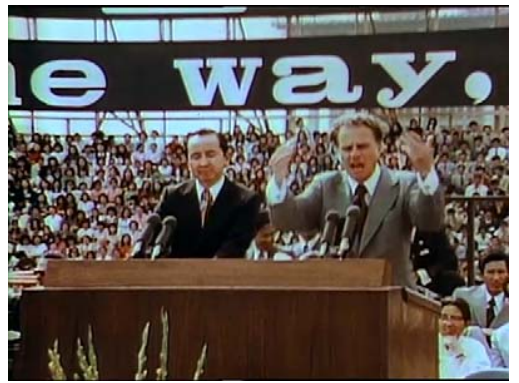

FIGURE 15 .

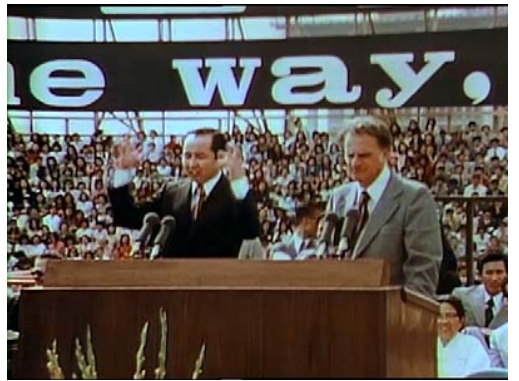

FIGURE 16.

5. G: And Eve looked at it.

6. K: Haewa ka kŭ yŏlmae rŭl poassŭmnida.

7. G: She was very curious.

8. K: Koengjanghi hogisim $\breve{u l}$ kajigo pomnida.

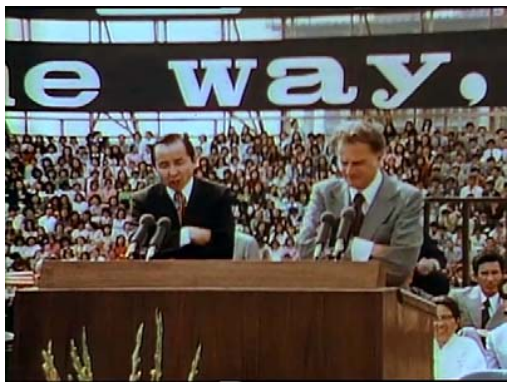

FIGURE 17.

9. G: How would it taste?

10. K: Ŏttŏk'e masissŭlkka?

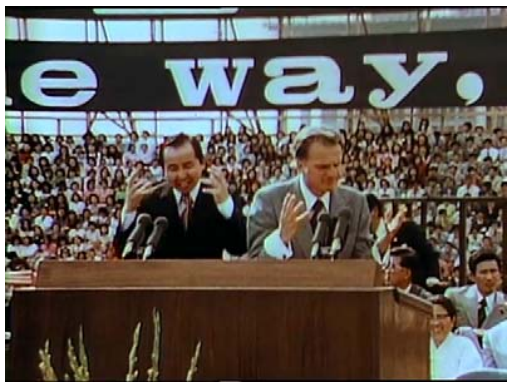

FIGURE 18 . 
11. G: It looked good.

12. K: Koengjanghi pogi enŭn t'amsŭrŏunde.

13. G: And then the devil came and whispered in her ear.

14. K: Kŭ taŭm e magwi ka kwi eda taego soksagimnida.

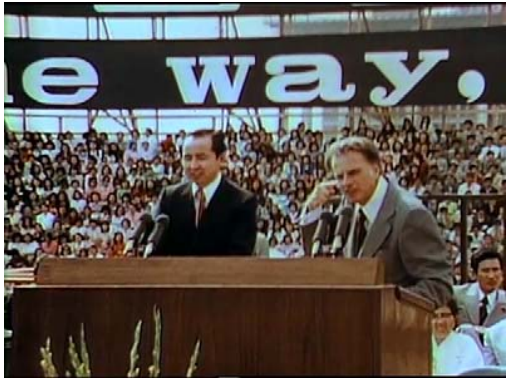

FIGURE 19

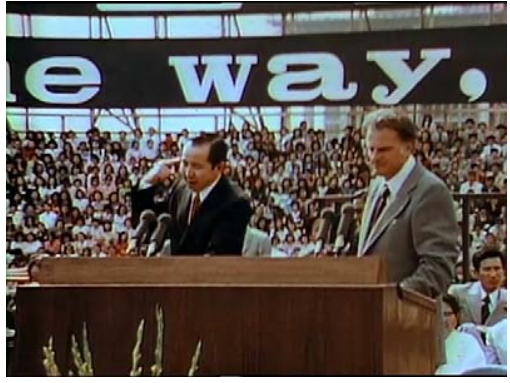

FIGURE 20 .

15. G: He said, Oh, take some of it.

16. K: Chom mŏgŏ posyŏ.

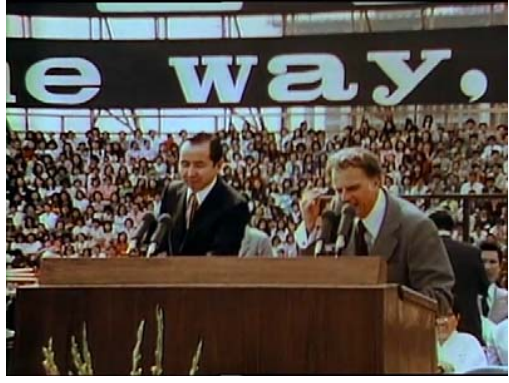

FIGURE 21 .

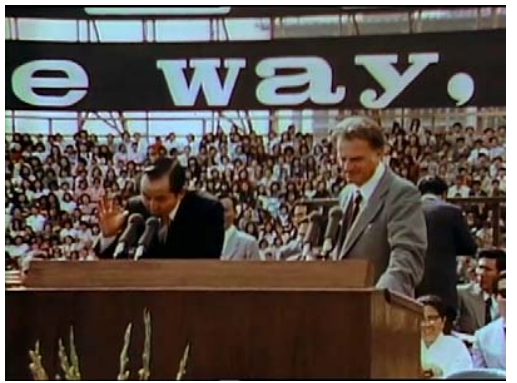

FIGURE 22 .

In Graham's and Kim's coordinated utterances, the moral figures are encountered not only through what they say but also through the way they say it. The complex bundling of nuances of vocal timbre, accent, and prosody contributed to distinctive register effects across metricalized segments of the sermon. That is, the effect of the specific combination and differentiation of the vocalized features of the utterances was that these utterances could be interpreted first as biblical voicings of good and evil, purity and temptation, and then allegorically generalized according to a social range of characterological figures who are recognizable as " speaking just like that'or "just like what one might expect from those people." 39 The vocal actions 
of two preachers who narrated the event and the characterological stereotypes of moral figures that emerged within their narration exerted moralizing pressure on certain forms of speech. This pressure produced voicing relations that both demarcated and blended the speech of characterological figures and the narrators. The identifiable characteristics of some of these voices leaked into the evangelists' narrative framing of their actions (apart from their actual quoted utterances). With the help of pitch visualization, we can follow the way certain characterological voices leaked-deictically and sensuously_into the narrating evangelists' voices.

Table 2 is a visualization of the variation of pitch over time in transcript 2, which I have segmented and labeled according to line number (1, 2, 3, and so on), preacher (Graham or Kim), and relation between narrating and narrated voices (direct report, free indirect "voicing," and so forth). We can first notice the marked shift in intonation and timbre from lines $1-4$, which contain direct reports of the deity's speech to Eve, to lines 5-8, which contain a description of Eve's actions and thoughts. In addition to shifting intonation and timbre, the two preachers also changed their carriage and gestures (crossing their arms and leaning forward), bodily inhabiting as a first-person perspective what they describe in the third-person perspective: Eve looking at the fruit. Although lines 5-8 are objective descriptions of Eve's actions and thoughts, the signs of her subjective feelings of temptation come through in the description and begin to fuse the event of narration with elements of the narrated event. This process of fusion culminates when Eve's perspective breaks through and takes over verbally in lines 9-12. Here, the two preachers continue to gesture from Eve's perspective, now with the effect of speaking in free indirect style to convey Eve's curiosity and the seductive power of temptation: they embed the temporal, spatial, and person deixis of a subordinate clause within an indirect report without the matrix clause to frame it. Even though Eve's speech is never quoted directly in this particular excerpt of the sermon, we have a sense of her voice-we can "hear" it-because of its sequential position and, as shown in the pitch visualization, by the more erratic intonation that is linked to her temptation and agitation. In lines 9-12, Eve's perspective breaks through into the preachers' coordinated narration of her actions. Finally, as the preachers report on the nefarious actions and tempting speech of the Devil in lines 13-16, they return to an intonation pattern that most closely resembles Eve's initial curiosity in lines 5-8.

Let me offer another, contrasting example here of a moment in which the vocalizations of the two preachers again produce a characterological figure that they momentarily inhabit. What is interesting about this later moment is that Graham's and Kim's intonation patterns are different one from another, but they are still rhythmically calibrated across their 
TABLE 2. Pitch visualization of transcript 2

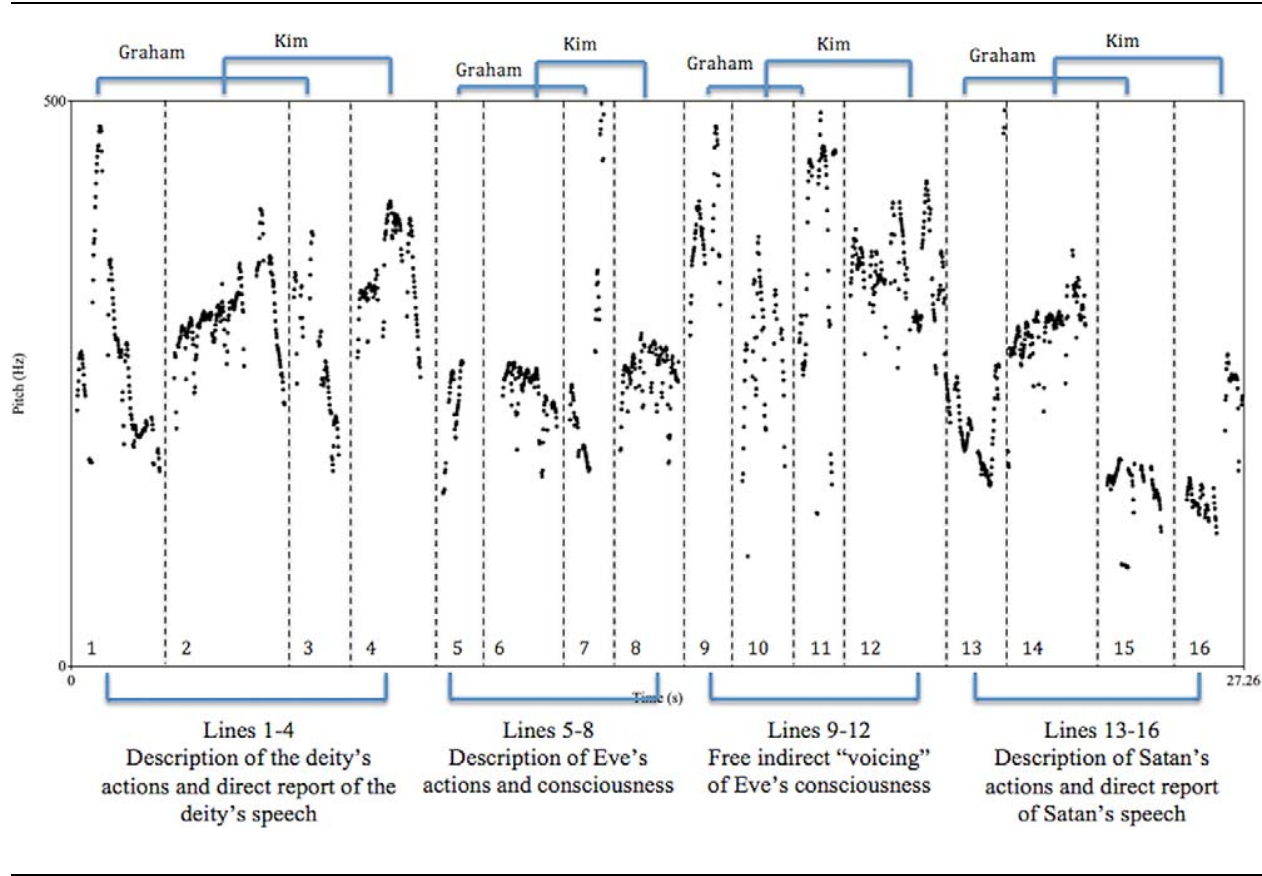

sequential utterances. This excerpt takes place later in the sermon (transcript 3, table 3), as the two preachers fixate on foundational messages in the Bible, intensifying their vocalizations as concrete material manifestations of these intensified messages. Again quoting the deity's command, the preachers align themselves with the voice of God as they list with conviction and unwavering focus the peoples of the world who must repent. While there is clearly coordinated rhythmic emphasis across the English and the Korean utterances, the prosodic target of the emphasis emerges as different. Whereas Graham's prosodic emphasis lands on the various people-Americans, Russians, Chinese, Europeans, Koreans-who must repent, Kim's emphasis lands on the term "repent" (hoegae) itself. This potentially has to do with a prosodic difference between English's (subject-verb-object) highly productive form of phonological stress for semantic emphasis and Korean's (subject-object-verb) use of particles and word order for emphasis and topic marking. The effect is a difference of sermonic focus: Graham's prosodic emphasis lands upon the universality of the Christian message; Kim's lands upon on the act that Koreans, like others, must carry out. Combined, however, the two preachers rhythmically achieve a united command-a kind of boom-chack, boom-chack, boom-chack effect-that 
poetically links their voices into a single message, even while they remain prosodically different. It is as if Graham calls out, "Everyone!" to which Kim adds, "Repent!"

\section{Transcript 3}

[46:18-46:26]

1. The Scripture says, God now commandeth all men everywhere to repent.

2. Sŏnggyŏng ŭn mal hagirŭl modŭn saram $i$ hoegae hal kŏt ŭl myŏng hanora.

[46:27-46:38 omitted]

[46:39-46:51]

3. Americans have to repent!

4. Miguk saram to hoegae haeya toemnida!

5. The Russians have to repent!

6. Soryŏn saram to hoegae haeya toemnida!

7. The Chinese have to repent!

8. Chungguk saram to hoegae haeya toemnida!

9. The Europeans have to repent!

10. Kurap'a saram to hoegae haeya toemnida!

11. The Koreans have to repent!

12. Han'guk saram to hoegae haeya toemnida!

TABLE 3. Pitch visualization of transcript 3

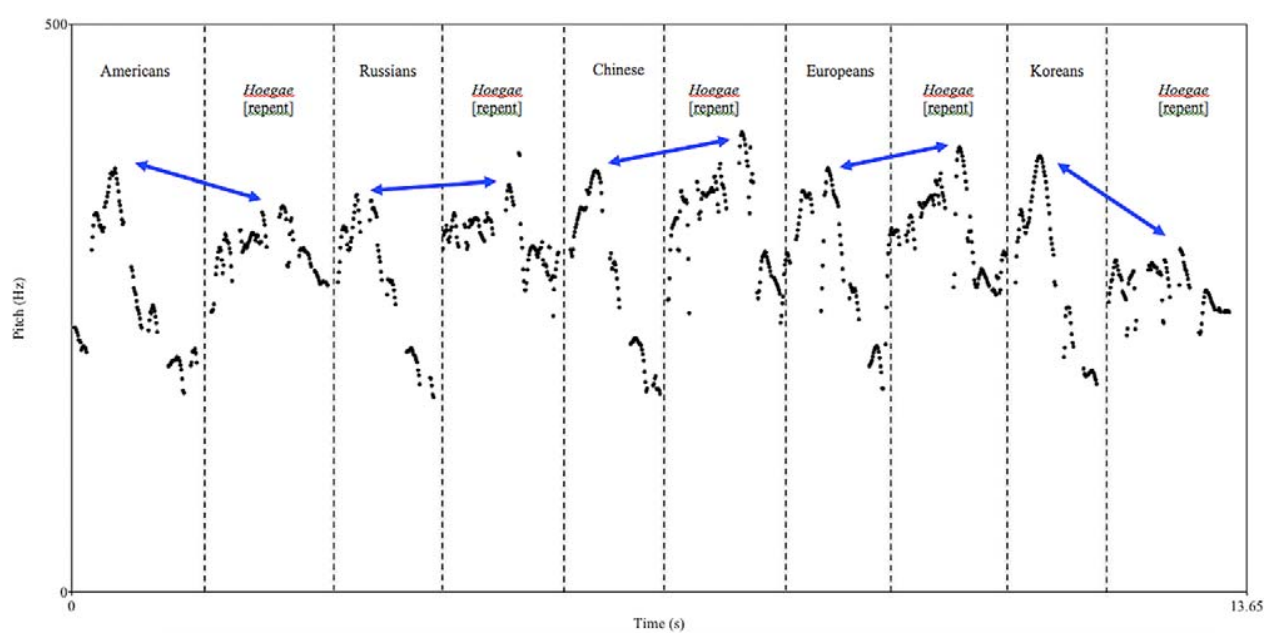


In both cases, characterological figures become linked with vocal styles that are differentiable across segments of the emergent text. The compounding, repetitive, monologic pattern of command in transcript 3-like Graham's earlier command to "love one another"-sharply contrasts with the more complex, nuanced polyphony in transcript 2. This contrast is made possible through the textual poetics by which Graham and Kim phonically produce the sensuous vocal landmarks to which they sonically orient as they introduce the various figures of personhood into the sermon. The qualia that link their phonosonic voices to their characterological voicings produce a dense, sensuous narrative environment of competing moral perspectives. This density becomes the semiotic condition that allows Eve's voice-affected by the Devil's temptation-to break through into the narrators' voices as an identifiable figure of alterity. ${ }^{40}$ This space also produces the semiotic conditions that allow the deity's voice to break through into the narrators' voices both as a qualitative contrast to Eve's (and the Devil's) voice within the narrative and as a generalized command to all in attendance and all peoples of the world ("Everyone repent!"). In this way, the formulation of a moral chronotope of evangelism and sacrifice introduced early in the sermon becomes filled with characterological attributes qua moral voicings in competition one with another. The coordinated utterances of the two preachers become increasingly fused as they navigate, side-by-side, utterance-byutterance, the emergent polyphonic vocal space of their sermon.

\section{Universalizing Individuation}

By formulating a chronotope of sacrifice and evangelism, and by populating the chronotope with sensuously differentiated, morally saturated characterological voices, the pastors are able to appropriate allegorical orientations and the transitive "principal" of evangelism to speak directly to members of the audience (transcript 4, figs. 23-29). They do this by generating the effect of addressing members of the audience individually (like a politician on stage pointing and smiling at individuals in a vast audience, as if there really were a single person out there corresponding to each point and smile). They simulate these targeted acts of address in order to ratify members of the audience as individuated participants in a massive interactional frame that is justified according to the universality of their message. Throughout the sermon, Graham addresses the audience with the second-person referential index "you." To this he adds prosodic and gestural cues that specify that each "you" is aimed at a biographical individual (albeit unspecified), not at the entire audience. In transcript 4, which takes place early on in the sermon, Graham points in one direction to the audience and asks, "Do you believe in God?" 
(line 1). He then asks the same question, but points in another direction and shifts his prosody to differentiate the target of his address: "Do you believe in God?" (line 3). Kim responds to these shifts in footing by starting with a plural "you" (yŏrŏbun) (line 2), and then switches in the second utterance to singular "you" (tangsin) (line 4), which, in the general case of the second-person singular indexical, is normally avoided in Korean. ${ }^{41}$ When Graham claims that God is a spirit and then points to an individual in the audience and announces, "Now God doesn't have a body like yours" (line 11), Kim again uses the second-person plural indexical yorrŏbun combined with the individuating gesture of pointing, but then he repairs the indexical contradiction (between a plural address and an individuating gesture) by pointing to himself, producing through gesture the indexical effects of a kind of kind of lastminute "us." Kim's rapid repair seamlessly links the scope of reference to the "everyone" that initiates Graham's earlier utterance in lines 5 and 7.

\section{Transcript 4}

[30:19-30:42]

1. G: Do you believe in God?

2. K: Yörŏbun Hananim ŭl mitsŭmnikka?

3. G: Do you believe in God?

4. K: Tangsin to Hananim ŭl mitsŭmnikka?

5. G: Everyone believes in a supernatural being.

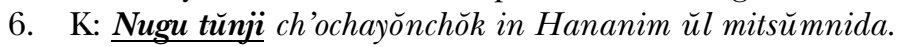

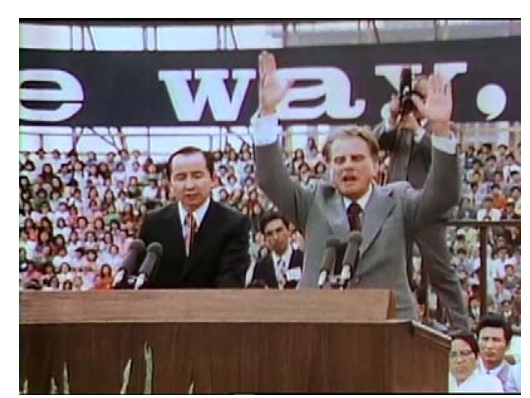

FIGURE 23.

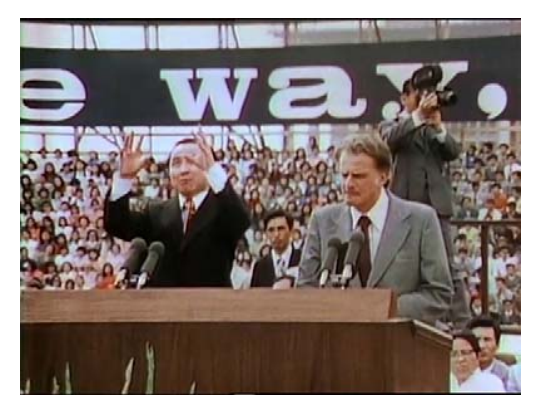

FIGURE 24.

7. G: Everybody believes there's a god somewhere.

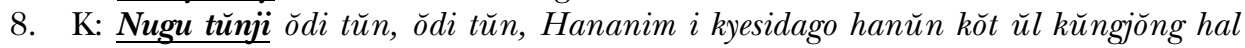
kŏmnida.

9. G: Now the Bible tells us what kind of a god he is.

10. K: Sŏnggyŏng ŭn ŏttǒhan Hananim irago hanŭn kŏt ŭl uri ege karik'yŏ chugo issŭmnida. 


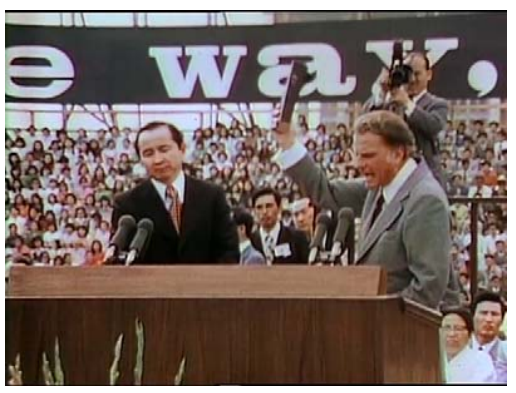

FIGURE 25 .

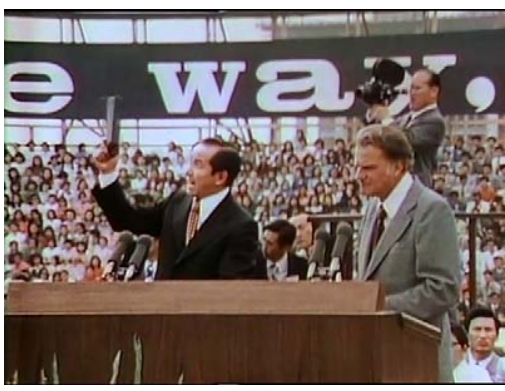

FIGURE 26.

[30:43-31:04 omitted]

[31:05-31:09]

11. G: Now God doesn't have a body like yours.

12. K: Hananim ǔn yŏrŏbun kwa kat'ŭn yukch'e rŭl kajigo kyesiji ansŭmnida.

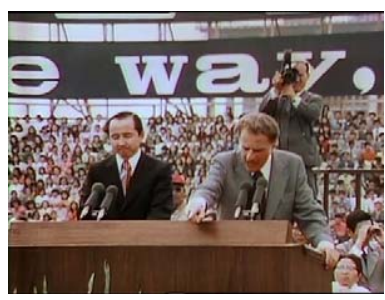

FIGURE 27.

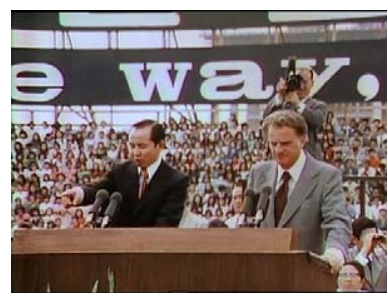

FIGURE 28.

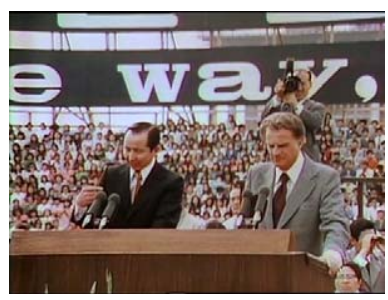

FIGURE 29 .

This pointing to the self, then, seems to be a key gesture in the transduction of Graham's complex web of temporal, spatial, and person deixis. The pastors point to the sky, indicating a supernatural being in heaven above as a cardinal, allocentric, and unchanging point of orientation for all. They wave their Bibles- "held at arm's length like the universal can opener" - as a hybrid point of orientation with the unchanging, eternal "Word" as circulating text instantiated as multiple materialized copies, that is, two books (text-artifacts) that two persons can hold separately. ${ }^{42}$ And they point to their individual bodies as thoroughly egocentric and inalienable, a site of radically personal Christian experience (figs. 30-33).

Historically situated, biographic individuals confront timeless universals through the processes of evangelical transduction across linguistic-cultural contexts (transcript 5). This moral web of indexicality becomes denser and more structured as the sermon proceeds, placing metapragmatic pressure on the pragmatics of its unfolding. That is, the underdeterminacy of the 


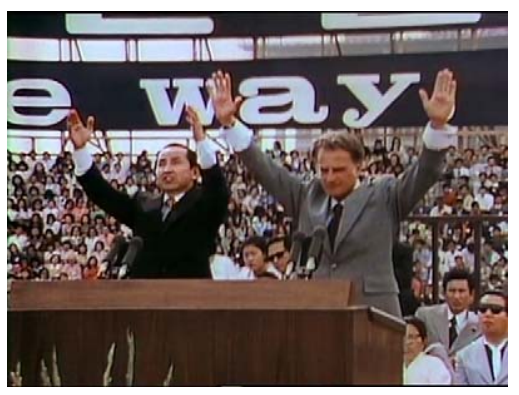

Figure 30. Allocentric: A supernatural being in heaven above as a cardinal, allocentric, unchanging point of orientation for all.
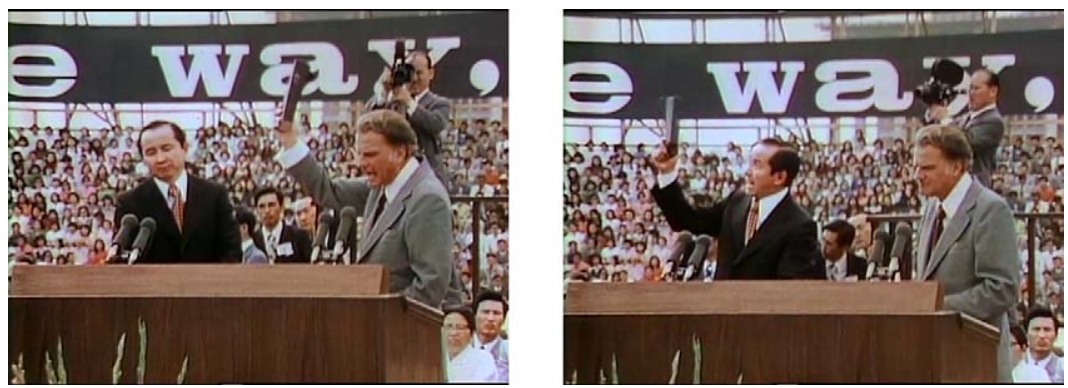

FIgures 31, 32. Hybrid: The Bible as a hybrid point of orientation with the unchanging, eternal "Word" as circulating text instantiated as multiple materialized copies-here, two books (i.e., text-artifacts) that two persons can hold separately.

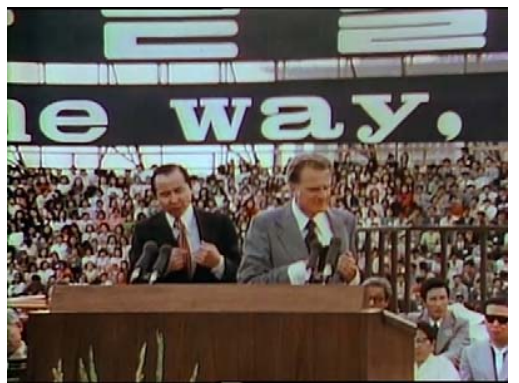

FIGURE 33. EgOCENTRIC: The body as thoroughly egocentric and personalized; time and space as radically individualized.

various indexical signs mobilized by the preachers becomes increasingly constrained and determined by the progressively clear, self-anchoring poetic dimensions of the sermon. In transcript 5, deictic focus ultimately 
lands on the here-and-now of the crusade, when Graham and Kim tell the crowd "We may never see a sight like this in Korea again" (line 7), "What a moment to receive Christ" (line 9), "He'll come to live in your heart" (line 15) and both men point to their own, individual hearts (see, again, fig. 33). With this move, the pastors deictically enclose the time-space of the entire sermon within the gathering itself, drawing purportedly universal, timeless truths revealed by historically situated events into the immediate here-andnow of the event and its participants.

\section{Transcript 5}

[49:09-49:39]

1. G: There are tens of thousands of people here today that do not know Christ.

2. K: Onŭl yogi suman-myŏng ŭi kunjundtŭl $i$ Yesu rŭl morŭsinŭn pundŭli kyesimnida.

3. G: And this is the last hour of this crusade.

4. K: I chŏndo chiphoe ŭi majimak sigan imnida.

5. G: It will soon be over.

6. K: Ije taŭm chu ihu enŭn ta kkŭnmachi'imnida.

7. G: We may never see a sight like this in Korea again.

8. K: Uri nün Han'guk esŏ irǒhan kwanggyŏng ŭl tasi nŭn poji mothallŭnji morŭgessŭmnida.

9. G: What a moment to receive Christ.

10. K: Yesu rŭl minnŭn ŏlmana choŭn sun'gan imnikka?

11. G: Let him come and change your life.

12. K: Yesu ka yŏrŏbun maŭm türŏwasŏ pyŏnhwa sik'yŏya toekessŭmnida.

[49:40-49:54 omitted]

[49:55-50:01]

13. G: If you'll do that.

14. K: Yŏrŏbun i kŭrŏk'e hasimyŏnŭn.

15. G: He'll come to live in your heart.

16. K: Yŏrŏbun maŭm e Yesunim kkesŏ sasil kŏmnida.

\section{Conclusion:}

"You Stand Up Right Now"

In his crusades, Graham often asked members of the audience to stand and approach the pulpit to receive Christ. With more than one million people in attendance at the Seoul event, this clearly was impossible. The final sermon there ended with Graham's request for people to stand and remain in their place as a first step on the road not just to belief but also to evangelism. He asked them to "give up all other gods" and "take a public stand for Christ" 
within a moral chronotope of sacrifice and a voicing structure that blends individual, sincere utterances with universal, unoriginal content. The preachers told the audience that a "counselor" (sangdamja) would come to them with some literature. Like the two preachers with their Bibles and their utterances, these counselors would literalize the metaphor of the "Word" that travels to those who wish to receive it and actualize the deity that speaks to those who wish to hear it. Drawing together the semiotic resources of the sermon to produce a ritual culmination of spiritual presence in the here-andnow of conversion, Graham told the audience: "Stand up. And say, 'Today I want to receive Christ." 43 The compounding of utterances, gestures, and now full-body action drew the attendees into a specifically South Korean Christian temporality of "now" and spatiality of "here" that was manifest as the presence of a living God speaking to and through a standing, uttering body. ${ }^{44}$

As Graham proceeded to command the audience to stand and speak, Kim transduced the force of the command into a form appropriate and effective for an audience that was still learning about the transitive "principal" of evangelism. Rather than directly reproducing Graham's blunt command in Korean, Kim made use of the three central indexical constraints I have discussed-the chronotopic formulation, the moral voicing structure, and the universalized individuation of the "Word" - to approximate the evangelical pressure of Graham's English utterance in a specifically Korean interactional frame. He achieved this specifically Korean cotextuality of denotation and interaction through a kind of deictic displacement. Rather than simply translating Graham's singular second-person address, Kim used the explicitly plural form (that is, yŏrŏbun rather than tangsin; see transcript 2), but specified, repeatedly, that this address was limited to those who intended to or had made the personal, individual decision to believe. This adjustment foregrounded the invitation to the audience to inhabit the personal, individual role of "I" / Na in the phrase "I want to receive Christ. / Na nün Yesu rŭl yŏngjŏp hagessümnida." Furthermore, Kim took up Graham's directive to stand "right where you are / kŭ chari eso $\breve{o}$ " and repeated it in multiple places where Graham did not, at once preventing a stampede and also reinforcing the individuated time-space of a person's conversion experience. Finally, just as with the earlier command to "love one another" (transcript 1), Kim transformed the blunt command into a respectful request, this time adding the sentence-final verb parada: to hope, wish, ask, or request. In transcript 6, I have noted these and other salient moments when Billy Kim departed from Billy Graham's phrasing to effectively transduce the force of Graham's evangelism specifically for the crowd in Seoul while preserving and adhering to universality of the "Word." Each of Kim's modifications and strategic departures amplified Graham's message while shaping and transforming it for maximal interactional effect (figs. 34-41). 


\section{Transcript 6}

[50:19-52:18]

1. I'm going to ask you today to receive Christ.

2. Na nŭn onŭl yŏrŏbun Yesu rŭl yŏngjŏp hagirŭl wŏn hamnida.

3. I'm going to ask you to do it publicly.

4. Yŏrŏbun i kwanjungdŭl moim kaunde esŏ Yesu rŭl mitki[in the middle of this gathering of spectators]

5. I'm going to ask you to stand up right where you are.

6. Yörŏbun $i$ anja kyesin kŭ chari esŏ Yesu mitkiro chakchŏng hanŭn pundŭl ŭl irŏsŏ rago hagessümnida.

[the people who intend to believe in Jesus]

7. Stand up.

8. Kŭ chari esŏ irŏsŏ chusigi paramnida.

[In that place] [respectfully ask]

9. And say, today I want to receive Christ.

10. Irŏsŏmyŏnsŏ na nŭn Yesu rŭl yŏngjŏp hagessŭmnida.

11. You may be a member of the church.

12. Yŏrŏbun $i$ kyohoe nagasinŭn pun inji morŭgessŭmnida.

13. But you're not sure that Christ lives in your heart.

14. Kŭrŏna yŏrŏbun maŭm e Kŭrisŭdo ka sanŭnji ajik morŭnŭn pun.

[heart-mind]

15. But you want to be sure.

16. Kŭrŏna onŭl hwaksiri algi rŭl wŏn hanŭn pun.

17. But for thousands of you it will be the first time.

18. Ama such'ŏn-myŏng ŭn ch'ŏŭm üro Yesu rŭl mitke toesil kŏmnida.

[first time to believe in Jesus]

19. I want you to stand up and say, today, I'm willing to turn from my sins. I want Jesus in my heart.

20. Ije ch'ŏŭm mitkiro chakchŏng hasinün pundŭl ŭn kŭ chari esŏ irŏnasŏ [the people who intend to believe for the first time, in that place] nae ka Yesu rŭl yŏngjŏp hago sae saram i toegessümnida.

[I would receive Jesus and become a new person]

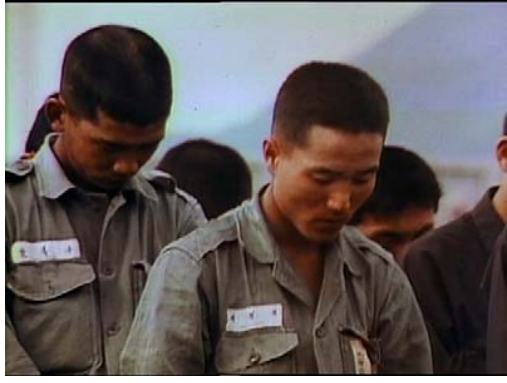

FIGURE 34.

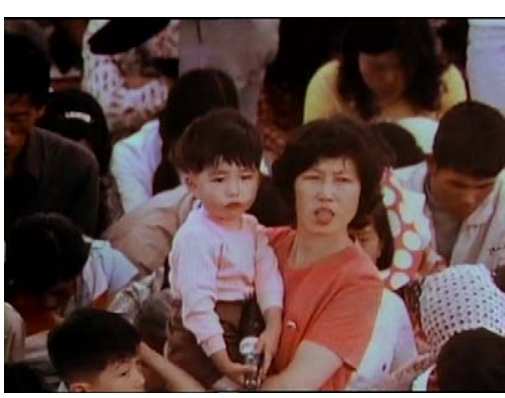

FIGURE 35. 
21. Stand right where you are.

22. Yörŏbundŭl kŭ anjŭn chari esŏ kŭdaero Yesunim minnŭn pundŭl ŭn, Yesu mitkiro chakchŏng hanün pundül ŭn irŏsŏ chusigi paramnida.

[All of you in that place where you are sitting, just as you are, the people who believe in Jesus, the people who decide to believe in Jesus, (we) respectfully ask you to stand.]

23. And keep standing.

24. Kyesok sŏ kyesigi paramnida.

[respectfully ask]

25. And then in a few minutes, we're going to bring you some literature.

26. T'ükpyŏri sŏsin pundül ege nŭn ch'aekcha rŭl türigessŭmnida. [Especially to the people who have stood]

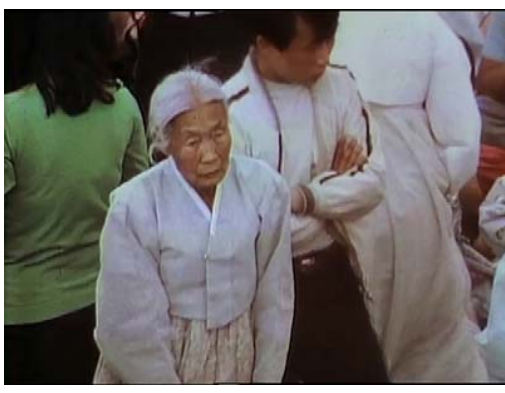

FIGURE 36.

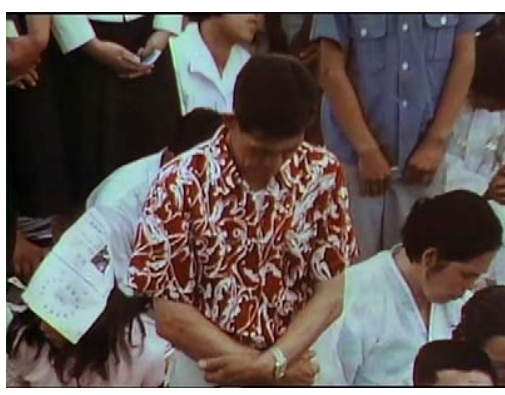

FIGURE 37.

27. And we're going to have a prayer with you.

28. Kŭ sun'gan sŏn pundŭl ŭl wihaesŏ kido rŭl haedürigessŭmnida.

[At that moment, for those people who have stood]

29. You don't need to move from where you are.

30. Yŏrŏbun $i$ sŏ innŭn chari esŏ umjigisil p’ilyo ka ŏpsŭmnida.

31. Just stand up and keep standing.

32. Kü chari esŏ irŏna sŏ chusigirŭl paramnida.
[At that place]
[respectfully ask]

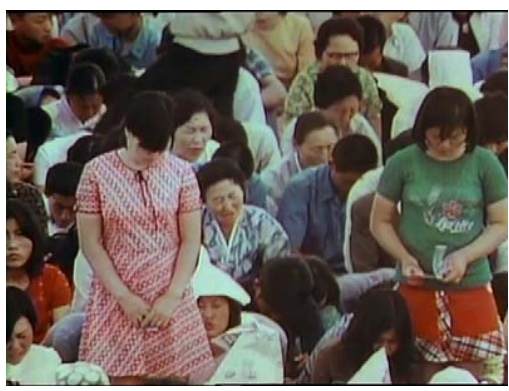

FIGURE 38. 
33. And say, on this day, this historic day, I receive Jesus Christ openly and publicly.

34. Onŭl $i$ yŏksajŏk in nal na nŭn saramdŭl ap'esŏ Yesu rŭl mitkiro kyŏlsim hagessŭmnida.

[I shall decide to believe in Jesus in front of people]

35. And a councilor will come to you where you are.

36. Yŏrŏbun $i$ sŏ kyesimyŏn ŭn sangdamja ka yŏrŏbun ŭl ch'ajagasil kŏmnida.

37. You may be an American soldier.

38. Yŏrŏbun i Miguk kunin idŭnji

39. You may be a Korean soldier.

40. Han'guk kunin idŭnji

41. You may be an ordinary citizen.

42. Ttohan kŭnyang p’yŏngmin idŭnji

43. But God has spoken to you today.

44. Hananim i yŏrŏbun ege malssŭm ŭl hasyŏttamyŏn.

45. You stand up right now.

46. Yŏrŏbun i sigan e Yesu mitkiro chakchŏng hamyŏn irŏsŏ chusigi paramnida. [at this time, if you intend to believe in Jesus] [respectfully ask]

47. And say "yes" to Christ.

48. Kürisŭdo rŭl yŏngjŏ [(We) respectfully ask you to receive Christ.]

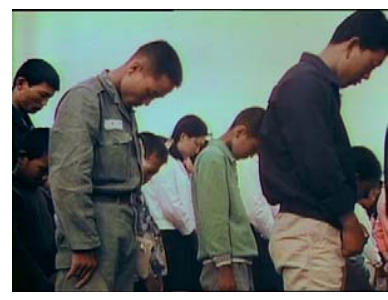

FIGURE 39.

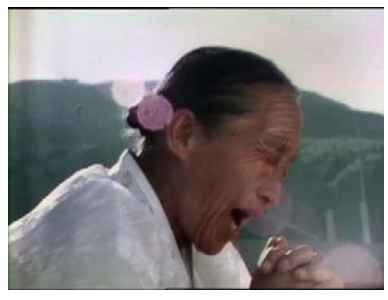

FIGURE 40 .

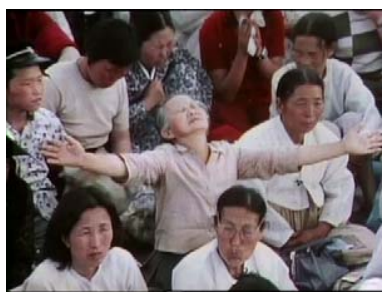

FIGURE 41 .

From line 47 to 48, Billy Graham's blunt command in English becomes Billy Kim's respectful request in Korean. Graham told his audience that "God has spoken to you today" and instructed them to "say 'yes' to Christ." Although many at the crusade were already Christians (the churches actively mobilized attendance), many others had not yet been instructed on how to speak back to this deity. There are a number of possible glosses for "yes" in Korean, all of which are saturated with overt pragmatic value based on explicit norms of interaction. The most common is the generally "polite" form $n e$. There is also ye, a markedly deferential form. $\breve{U} g$ and $\breve{o}$ are the least deferential and most informal (for example, normally used reciprocally among friends or asymmetrically to inferiors). Eventually, they would learn 
to use the most elaborate honorific forms, the highest levels of respect, the most archaic sentence endings, to address this deity. But Billy Kim, in June of 1973, after having insisted, beyond Graham's directives, that the audience stand in their place, and, crucially, that only those who intend to believe should stand, rather than bluntly commanding the audience to "say 'yes' to Christ," respectfully asked them to receive Christ.

In the prior examples in this paper, I showed how Graham's and Kim's individual utterances become increasing calibrated as the two pastors aligned themselves to the chronotopic formulation of sacrifice and evangelism through which the crusade could be conceptualized and justified; to the temporal, spatial, and person deixis through which participants in the event could be drawn into and situated within this chronotope; and to the voicing structures in terms of which these participants could align with or distance themselves from different moral perspectives. In this final example, however, as the two pastors entered the crucial final phase of the sermon, they diverged more than at any other point. As Graham prepared to "go back to America," Kim spoke most directly to those who, like him, would remain in South Korea. It is as if, in the spatiotemporal model of the movement of the "Word" developed over the course of the sermon, the "Word" had nearly passed from Graham to Kim. There, within the internal poetic structure of the sermon, the "Word" was most fully Koreanized, was directed most specifically to the vast crowd gathered before them, and adhered most tightly to the pragmatic expectations of Korean interaction. It is from this point - as those in attendance were asked to stand and speak, the crucial point of local "uptake" by more than one million individuals en massethat the "Word" would emerge and circulate within a specifically South Korean domain of cultural semiosis, and thence out into the world in the form of Korean evangelical missions abroad.

With each coordinated multimodal event of semiotic production, the act of interpretation from English to Korean became an indexical icon of the long line of evangelists who had spoken across code and culture "in the name of Jesus." And to speak "in the name of Jesus," as the transitive "principal" of evangelism, continues to justify for Korean Protestants their missionary efforts throughout the world. Such a metapragmatic frame gives these evangelists the pragmatic authority not simply to speak as Christians, but to speak as Christian evangelists to others-to persuade and even command them, that is, to appropriate and channel the authority of the "Word" in all of their interactions. This authorized use of illocutionary force was affirmed when Billy Graham said to his audience in Seoul in 1973, "You have the power to change all of Asia."

With Billy Graham and Billy Kim aligned at the pulpit, tightly calibrated across multiple semiotic modalities, with apparent parity and direct access 
to a deity still new to many Koreans, a structural position for South Korea was staged as a future source of world evangelism. In such an event, a Christian promise for postwar South Korea's place in the Cold War world was established, performed, and dispersed. Billy Kim's virtuosic transduction of Billy Graham in 1973 was a dramatic departure from what might at first seem like the studied voicelessness of interpreters that we are used to, for example, in institutional reports or broadcast news. Rather than serving as a transparent medium for the reproduction of information across codes, and rather than simply producing a sermonic copy of a famous preacher, Kim himself became a charismatic model of Korean evangelism and a charismatic source of evangelical momentum. In their 1973 crusade, Billy Kim and Billy Graham performatively created a conduit for the movement of the "Word."

\section{Notes}

I am grateful to the editors of this special issue of Representations, Michael Lucey, Tom McEnaney, and Tristram Wolff, for their extensive written comments on this paper. An earlier draft was presented at a lively session of the American Comparative Literature Association organized by the editors in 2016. I also presented earlier versions at the annual meeting of the American Anthropological Association (2014), Seoul National University (2015), and the University of Washington (2016). I gratefully acknowledge the permission of the Billy Graham Evangelistic Association to reproduce the film stills and photographs in this paper. The research for and writing of this article were supported by a Rockefeller Foundation Fellowship at the National Humanities Center and an Academy of Korean Studies Grant funded by the South Korean Government (MEST) (AKS-2011-AAA-2104), in collaboration with the Max Planck Institute for the Study of Religious and Ethnic Diversity.

1. In 1973, construction projects were underway for two major architectural sites: the National Assembly building, which was completed in 1975, and the Yoido Full Gospel Church, which was completed in 1973 and hosted the Tenth Pentecostal World Conference in September of that year. Claiming hundreds of thousands of members, the Yoido Full Gospel Church now is the largest Protestant church in the world. See Nicholas Harkness, "Other Christians as Christian Others: Signs of New Christian Populations and the Urban Expansion of Seoul," in Handbook of Religion and the Asian City: Aspiration and Urbanization in the Twenty-First Century, ed. Peter van der Veer (Berkeley, 2015).

2. Monitors estimated the size of the crowd by determining the density of people within rectangular sections of the asphalt plaza. See John Pollack, Billy Graham: Evangelist to the World: An Authorized Biography of the Decisive Years (New York, 1979), 54-62.

3. In 1973, Billy Jang Hwan Kim was not merely a self-identified Christian but also an up-and-coming Baptist preacher. Born in 1934 to a poor family, Kim received a position as a houseboy for the US military. The American soldiers found the Korean name "Jang Hwan" too difficult to pronounce, so they began to address Kim as "Billy." A sergeant helped Kim move to the United States in 
1951 and enroll in the Bob Jones Academy in South Carolina. Kim returned to South Korea in 1959 and became a minister at the Suwŏn Baptist Church and eventually went on to be president of the World Baptist Alliance (2000-2005). Kim's biography easily becomes a metaphor for the more general postwar, Cold War, transpacific evangelical Christian relation between the United States and South Korea.

4. Kim compared these preparations to the time and effort he spent as a youth practicing his [r] and [1] liquid consonants in order to win an English speech contest. He also recounted the painful emotional conflict he experienced when agreeing to interpret for Graham, because of the ban his fundamentalist alma mater, the Bob Jones Academy, had placed upon associating with Graham. Billy Jang Hwan Kim, The Life of Billy Kim: From Houseboy to World Evangelist, trans. Sumi Lambe (Chicago, 2015), 77. The original Korean autobiography, Sómgimyŏ Sanŭn Kippŭm [The joy of serving and living] (Seoul, 2012), is written as a first-person account. The English translation is written as a third-person account.

5. Billy Graham Evangelistic Association (hereafter BGEA), "Billy Graham Crusade in Seoul, South Korea, 1973” (Charlotte, NC, 1973), https://www.youtube.com/ watch?v=QK7VhJV_iyo.

6. Far Eastern Broadcasting Company (hereafter FEBC), "Chisang Ch'oedae Ǔi Sŏngnyŏng K'onsŏt'ŭ, Ajik Kkŭnnaji Anŭn Yŏksa [The greatest Holy Spirit concert on earth, an unfinished history]" (2013), https://www.youtube.com/ watch?v=HzF6TP4qoXs.

7. BGEA, "Billy Graham Crusade in Seoul, South Korea, 1973."

8. FEBC, "Chisang Ch'oedae Ŭi Sŏngnyŏng K'onsŏt'ŭ, Ajik Kkŭnnaji Anŭn Yŏksa."

9. Ibid.

10. Pollack, Billy Graham: Evangelist to the World, 56.

11. Billy Graham: God's Ambassador, directed by Michael Merriman (Beverly Hills, 2006), DVD.

12. BGEA, "Billy Graham Crusade in Seoul, South Korea, 1973."

13. Michael Silverstein, "Translation, Transduction, Transformation: Skating 'Glossondo' on Thin Semiotic Ice," in Translating Cultures: Perspectives on Translation and Anthropology, ed. Paula Rubel and Abraham Rosman (Oxford, 2003). For a foundational paper on indexicality as the encompassing dimension language (relative to denotation, i.e., the specifically "symbolic" mode of language, in Peircean terms), see Michael Silverstein, "Shifters, Linguistic Categories, and Cultural Description," in Meaning in Anthropology, ed. Keith Basso and Keith Selby (Albuquerque, 1976).

14. BGEA, "Billy Graham Crusade in Seoul, South Korea, 1973."

15. Silverstein, "Translation, Transduction, Transformation." See also Richard Bauman and Charles Briggs, "Poetics and Performance as Critical Perspectives on Language and Social Life," Annual Review of Anthropology 19 (1990); Michael Silverstein and Greg Urban, Natural Histories of Discourse (Chicago, 1996). For a more expansive notion of transduction across semiotic modalities, see Webb Keane, "On Spirit Writing: Materialities of Language and the Religious Work of Transduction," Journal of the Royal Anthropological Institute 19, no. 1 (2013).

16. In other Christian settings, the term "interpretation" (tŏngyŏk hada) is used to describe the act of "translating" glossolalia ("speaking in tongues") into an intelligible code. Of course, every act of translation is also an act of cultural description and interpretation. See Courtney Handman, "Events of 
Translation: Intertextuality and Christian Ethnotheologies of Change among Guhu-Samane, Papua New Guinea," American Anthropologist 112, no. 4 (2010). See also Anthony Webster, "The Art of Failure in Translating a Navajo Poem," Journal de la Société des Américanistes 102, no. 1 (2016).

17. On the historical emergence of the genre and its characteristic features, see Michael Warner, "The Preacher's Footing," in This Is Enlightenment, ed. Clifford Siskin and William Warner (Chicago, 2010).

18. FEBC, "Chisang Ch'oedae Ǔi Sŏngnyŏng K'onsŏt'ŭ, Ajik Kkŭnnaji Anŭn Yŏksa." BGEA, "Billy Graham Crusade in Seoul, South Korea, 1973."

19. Roland Barthes, "Billy Graham at the Vel' D'hiv," in Mythologies [1957], trans. Richard Howard and Annette Lavers (New York, 2012), 110.

20. Billy Graham, quoted in "Interpreted, Billy Graham Wins One of 13," Chicago Tribune, June 6, 1955.

21. Ibid. On the "delegation" of voice, see Webb Keane, "Delegated Voice: Ritual Speech, Risk, and the Making of Marriage Alliances in Anakalang," American Ethnologist 18, no. 2 (1991).

22. On this problem in theories of translation more generally, see Susan Gal, "The Politics of Translation," Annual Review of Anthropology 44 (2015).

23. Michael Silverstein, "Axes of Evals: Token Versus Type Interdiscursivity," Journal of Linguistic Anthropology 15, no. 1 (2005). Christopher Ball, "Boasian Legacies in Linguistic Anthropology: A Centenary Review of 2011," American Anthropologist 114, no. 2 (2012): 205-6.

24. Nicholas Harkness, "Words in Motion and the Semiotics of the Unseen in Two Korean Churches," Language Eं Communciation 30, no. 2 (2010).

25. Webb Keane, Christian Moderns: Freedom and Fetish in the Mission Encounter (Berkeley, 2007).

26. Susan Harding, The Book of Jerry Falwell: Fundamentalist Language and Politics (Princeton, 2000), 24.

27. Keane, Christian Moderns, 216.

28. See Timothy S. Lee, Born Again: Evangelicalism in Korea (Honolulu, 2010).

29. Today, many of the largest Protestant congregations in the world are located in Seoul, and more than twenty thousand South Koreans are carrying out missions abroad. Center for the Study of Global Christianity, Christianity in Its Global Context, 1970-2020: Society, Religion, and Mission (South Hamilton, MA, 2013), 76; see also Ju Hui Judy Han, "Reaching the Unreached in the 10/40 Window: The Missionary Geoscience of Race, Difference and Distance," in Mapping the End Times: American Evangelical Geopolitics and Apocalyptic Visions, ed. Jason Dittmer and Tristan Sturm (Farnham, Surrey, UK, 2010); Ju Hui Judy Han, "Our Past, Your Future: Evangelical Missionaries and the Script of Prosperity," in Territories of Poverty: Rethinking North and South, ed. Ananya Roy and Emma Shaw (Athens, GA, 2015).

30. Erving Goffman, "Footing," Semiotica 25, no. 1-2 (1979).

31. Mikhail M. Bakhtin, The Dialogic Imagination: Four Essays (Austin, 1981); Asif Agha, "Chronotopic Formulations in Kinship Behavior and History," Anthropological Quarterly 88, no. 2 (2015).

32. On the relation between "voice" as a nexus of the phonic engagement with and sonic modes of orientation within cultural frameworks of value, and "voicing" as a higher-order semiotic alignment with a socially recognizable perspective, see Nicholas Harkness, Songs of Seoul: An Ethnography of Voice and Voicing in Christian South Korea (Berkeley, 2014). See also Bakhtin, The Dialogic Imagination, 316; Asif Agha, "Voice, Footing, Enregisterment," Journal of Linguistic Anthropology 15 , no. 1 (2005). 
33. Mikhail M. Bakhtin, Speech Genres and Other Late Essays, trans. Vern W. McGee (Austin, 1986), 163.

34. Michael Silverstein, "Metaforces of Power in Traditional Oratory," (lecture, Department of Anthropology, Yale University, New Haven, 1981).

35. For linguistic anthropological perspectives on the role of indexicality in gesture and linguistic deixis, see John Haviland, "Gesture," in Companion to Linguistic Anthropology, ed. Alessandro Duranti (Malden, MA, 2004). William Hanks, "The Indexical Ground of Deictic Reference," in Rethinking Context: Language as Interactive Phenomenon, ed. Charles Goodwin and Alessandro Duranti (Boulder, 1992).

36. The Korean term is panmal, literally "half-speech," which is normatively (but not exclusively) used reciprocally among intimates and asymmetrically when directed to subordinates, inferiors, juniors, etc.

37. Joel Robbins, "The Globalization of Pentecostal and Charismatic Christianity," Annual Review of Anthropology 33 (2004).

38. Nicholas Harkness, "The Pragmatics of Qualia in Practice," Annual Review of Anthropology 44 (2015); on the intersubjective orientation to sensuous pragmatic signals, see Lily Hope Chumley and Nicholas Harkness, "Introduction: Qualia," Anthropological Theory 13, no. 1/2 (2013).

39. Judith Irvine, "Commentary: Knots and Tears in the Interdiscursive Fabric," Journal of Linguistic Anthropology 15, no. 1 (2005): 75. See also Agha, "Voice, Footing, Enregisterment."

40. Adi Hastings and Paul Manning, "Introduction: Acts of Alterity," Language $\mathcal{F}^{\circ}$ Communciation 24, no. 4 (2004).

41. See Nicholas Harkness, "Basic Kinship Terms: Christian Relations, Chronotopic Formulations, and a Korean Confrontation of Language," Anthropological Quarterly 88, no. 2 (2015).

42. Barthes, "Billy Graham at the Vel' D'hiv," 111. On the tension between voice and denotational text in relation to Christian speech and divine presence, see Matthew Engelke, A Problem of Presence: Beyond Scripture in an African Church (Berkeley, 2007).

43. See Simon Coleman, "'Right Now!': Historiopraxy and the Embodiment of Charismatic Temporalities," Ethnos 76, no. 4 (2011).

44. I should stress that I am not rehearsing the familiar Austinian point, which treats denotation as logically prior to the indexical processes of social action and therefore is forced to explain how a "locutionary" utterance can take on extra "illocutionary" force. Linguistic and semiotic anthropologists have long maintained that the indexical dimensions of interaction-the "neglected situation" in Goffman's terms-are logically and empirically prior to denotation. From this methodological position, they have shown not only that utterances always "do" and "perform" social things in context but also that under saturated ritual conditions like the ones described here, the semiotic values of ongoing social action can be focused, condensed, and brought to awareness by coinciding with a description of that action-in effect explicitly "saying" what they already implicitly "do." See Michael Silverstein, "Language Structure and Linguistic Ideology," in The Elements: A Parasession on Linguistic Units and Levels, ed. Paul Cline, William Hanks, and Charles Hofbauer (Chicago, 1979). See also Benjamin Lee, Talking Heads: Language, Metalanguage, and the Semiotics of Subjectivity (Durham, NC, 1997). 